\title{
THE INFLUENCE OF CORTISONE ON EXPERIMENTAL FUNGUS INFECTIONS IN MICE*
}

\author{
By DONALD B. LOURIA, NANCY FALLON AND HARRY G. BROWNE \\ (From the Infectious Disease Laboratory, Second (Cornell) Medical Dizision, Bellevue \\ Hospital, Nez' York, the National Institute of Allergy and Infectious Diseases, \\ Bethesda, Md., and the Department of Pathology. The New York \\ Hospital-Cornell Medical Center, Nez' York, N. Y.)
}

(Submitted for publication January 28, 1960 ; accepted April 29, 1960)

The administration of adrenal glucocorticoids is associated with enhancement of many experimental infections. The pertinent studies have been reviewed comprehensively by Kass and Finland (1). Most experiments in which fungi were used as the infecting microorganism have also demonstrated an increase in the severity of infection when adrenal hormones were injected prior to or concomitantly with the fungus (2-9). A few studies, however, showed no augmentation of mycotic disease following the administration of steroids $(3,10-12)$.

The investigations on fungi have not provided information as to the relative propensity of the various species to disseminate under the influence of steroids, nor have they offered definitive data on the mechanisms of enhancement or on the tissue localization of increased infection.

The effects of cortisone on experimental infections in mice caused by Histoplasma capsulatum, Cryptococcus neoformans, and Candida albicans were compared in the present studies. The results show that Monilia infections were enhanced more readily than infections caused by either of the other two fungi. Further bacteriological and histological studies were then performed to delineate the pathogenesis of increased infection in candidiasis, and to analyze the effects of cortisone when the infecting inoculum was small and when steroid treatment was delayed.

* This work was supported in part by grants from the National Institute of Allergy and Infectious Diseases, Bethesda, Md. (E-2659), the Charles Pfizer Co., Inc., New York, The Health Research Council of New York City, The New York Trudeau Society, and Training Grant E-6 from the National Institute of Allergy and Infectious Diseases. A preliminary report of these studies was presented to the Second Conference on Medical Mycology held under the auspices of The New York Academy of Sciences, January 11 and 12, 1960.

\section{MATERIALS AND METHODS}

Mice. Two strains of mice were used. In all studies on histoplasmosis and cryptococcosis, and in some of the Candida experiments, female Swiss albino mice, 17 to $20 \mathrm{~g}$, from the National Institutes of Health $(\mathrm{NIH})$ were used. Mice of this strain tolerated up to $2.0 \mathrm{mg}$ cortisone per day for 28 days without weight loss or other noticeable deleterious effects, although some animals failed to gain weight during steroid administration.

In later experiments, male Swiss albino mice 17 to $20 \mathrm{~g}$, from Carworth Farms (strain CFW) were used. Mice of this strain consistently lost weight when $0.5 \mathrm{mg}$ of cortisone was administered daily for 5 to 9 days. Increase in the dosage of $1.0 \mathrm{mg}$ daily for 9 days produced death in up to 30 per cent of control animals. Experiments on moniliasis using this strain were included in the results after it was determined that death curves and tissue populations were similar to those obtained with $\mathrm{NIH}$ mice in both normal and cortisone-treated animals.

Mice of both strains were variably housed in glass jars, or in metal or plastic cages. They were fed mouse pellets and water ad libitum.

Fungus strains. Histoplasma capsulatum, strain 6624, was recovered from a patient with disseminated histoplasmosis in 1952. During serial weekly passage at $37^{\circ}$ $\mathrm{C}$, on blood-cysteine agar, it has not altered in pathogenicity for mice, killing at least 80 per cent of animals within 30 days following the intravenous inoculation of $5 \times 10^{6}$ yeast phase cells.

Cryptococcus neoformans, strain 1148, was recovered in 1954 from the cerebrospinal fluid of a patient with chronic cryptococcus meningitis. This strain, a large capsule strain, has not altered in pathogenicity for mice during semi-weekly serial passage on Sabouraud's agar slants incubated at $30^{\circ} \mathrm{C}$. After intravenous inoculation of $2.5 \times 10^{\circ}$ cells, 90 to 100 per cent of mice die within 8 weeks with gross hydrocephalus.

Candida albicans, strain 851, was recovered in 1956 from the oropharynx of a patient with clinical evidence of mucocutaneous moniliasis. It has been maintained by serial monthly passage on Sabouraud's agar slants incubated at $30^{\circ} \mathrm{C}$. There has been no change in mouse pathogenicity during this period. Five to 30 per cent of mice die within a 4 week period after the intravenous injection of $5 \times 10^{8}$ cells. When the inoculum is 


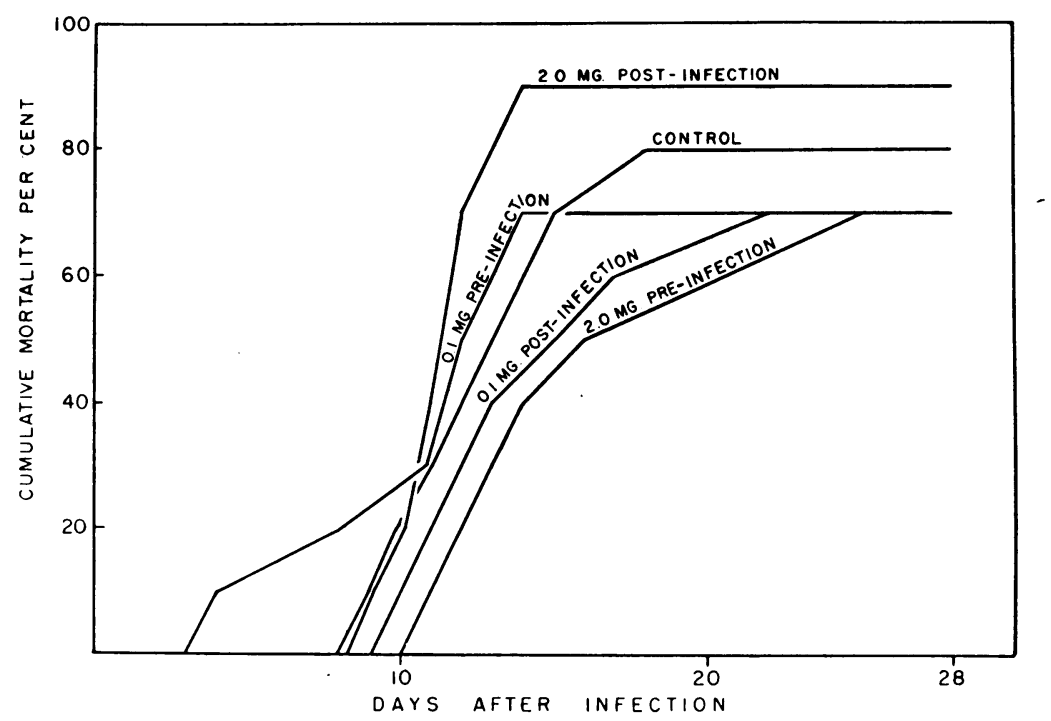

Fig. 1. EFFECT OF CORTISONE ON MORTALITY IN MICE FOLLOWING I. V. INFECTION WITH $1 \times 10^{6}$ CELLS of $H$. CAPSULATUM. Cortisone was administered intraperitoneally daily starting 6 days prior to (pre-infection) or the day following infection (post-infection) and was continued for 28 days after infection. Each group consisted of ten mice.

increased to $10^{7}$ cells, the majority of mice dies within 7 days of infection.

Infection. The infecting dose of $H$. capsulatum and $C$. neoformans ranged from $3 \times 10^{1}$ to $10^{z}$ cells per mouse in these experiments. The size of the Candida inoculum varied from $10^{3}$ to $5 \times 10^{8}$.

Candida and Cryptococcus inocula were emulsified in physiological saline from a Sabouraud's agar slant incubated for 24 hours at $30^{\circ} \mathrm{C}$. Histoplasma inocula were emulsified in saline from a 48 hour cysteine-blood agar slant incubated at $37^{\circ} \mathrm{C}$. The inoculum in each case consisted almost exclusively of yeast cells which were single or in pairs.

The size of the larger inocula was determined by direct fungus counts in a Neubauer-Levy hemocytometer. The number of fungus cells in smaller inocula was determined by making Sabouraud's agar pour plates of serial 10 - or 100 -fold dilutions of the injected suspension. Pour plates were incubated at $30^{\circ} \mathrm{C}$ and colony counts were made at appropriate intervals.

Cortisone. Cortisone acetate was purchased from Schering Corporation, Bloomfield, N. J. One-tenth to $2.5 \mathrm{mg}$ was injected subcutaneously or intraperitoneally in a $0.2 \mathrm{ml}$ volume. Cortisone was administered beginning 2 to 6 days prior to, or starting the day after infection, and was continued for 7 to 30 days after infection. In studies in which $2.5 \mathrm{mg}$ was administered, however, the steroid was only given the day prior to, the day of, and the day after infection, since more prolonged treatment at this dosage produced toxicity and death.

In two experiments on the effects of delayed treatment, administration of $0.5 \mathrm{mg}$ of cortisone was begun 7 days after the initiation of infection and was continued for 9 days.
In each experiment one group of 10 uninfected mice was given the maximum dose of cortisone used in the experiment to insure that deaths in infected animals could not be attributed to cortisone alone.

Tissue population studies. The number of fungi in tissues was determined in control and cortisone-treated mice on the seventh or fifteenth day after infection. In early experiments, liver and spleen or liver, spleen and kidneys were emulsified together in $5 \mathrm{ml}$ of physiological saline, ground with a mortar and pestle, and serially diluted in distilled water. One $\mathrm{ml}$ aliquots of appropriate dilutions were cultured on the surface of Sabouraud's agar pour plates.

Liver and spleen were chosen for studies of Histoplasma because there is clear pathological and bacteriological evidence that these are the organs of maximum census following experimental mouse infection $(13,14)$.

Liver and spleen were also used for fungus enumeration in Cryptococcus experiments after it was shown that progressive infection occurred in all organs studied including liver-spleen (which were combined), lung, kidney, and brain during the first 2 weeks after infection (15). Subsequently, more detailed quantitative studies in this laboratory have demonstrated that multiplication during the first 2 weeks was somewhat less in the liverspleen than in the lungs, kidney, and brain. It is possible, therefore, that the use of the combined liver and spleen for fungal census studies in cryptococcosis did not represent the most sensitive index of cortisone dissemination.

The kidney was added to the liver and spleen in the initial studies on moniliasis because there was considerable histological evidence that the kidney is extensively 
TABLE I

Effect of cortisone on intravenous fungus infections in mice

\begin{tabular}{lcccc}
\hline \hline Fungus & Inoculum size & Control* & $\begin{array}{c}\text { Cortisone } \\
(0.1 \mathrm{mg} / \text { day })^{*}\end{array}$ & $\begin{array}{c}\text { Cortisone } \\
(0.5-2.0 \mathrm{mg} / \text { day })^{*}\end{array}$ \\
\hline Candida & $10^{4}$ & $0 / 10$ & $0 / 20$ & $0 / 20$ \\
albicans & $10^{5}$ & $0 / 20$ & $0 / 40$ & $1 / 40$ \\
& $10^{6}$ & $3 / 30$ & $10 / 60$ & $21 / 60$ \\
Histoplasma & $5 \times 10^{6}$ & $8 / 70$ & $11 / 70$ & $59 / 70$ \\
capsulatum & $10^{4}$ & $0 / 10$ & $2 / 20$ & $0 / 20$ \\
& $10^{5}$ & $1 / 10$ & $2 / 20$ & $4 / 20$ \\
Cryptococcus & $10^{6}$ & $8 / 10$ & $14 / 20$ & $14 / 20$ \\
neoformans & $10^{7}$ & $10 / 10$ & $10 / 10$ & $10 / 10$ \\
& $2 \times 10^{4}$ & $1 / 10$ & $3 / 20$ & $3 / 20$ \\
& $2 \times 10^{5}$ & $7 / 10$ & $9 / 20$ & $10 / 20$ \\
& $2 \times 10^{6}$ & $9 / 10$ & $15 / 20$ & $14 / 20$
\end{tabular}

* The ratios given show the relationship between the number of mice killed and the number infected.

involved in normal animals following intravenous Candida infection $(16,17)$.

In the subsequent studies on the tissue localization of Candida infections, serial determinations were made separately on liver, spleen, heart, lung, kidneys, and brain 15 minutes to 60 days after infection. Organs in these later experiments were homogenized in $2 \mathrm{ml}$ of distilled water in a Teflon tissue homogenizer (18), and Sabouraud's agar pour plates were made of appropriate 100 -fold dilutions. All pour plates were incubated at $30^{\circ} \mathrm{C}$.

In some experiments in which tissue census was expected to be low, pour plates were made of the original undiluted organ homogenate. Control studies demonstrated that homogenates of normal mouse organs had no fungicidal effect on the growth of Candida. Thus, when known numbers of fungi were added to the homogenate, mixed thoroughly and enumerated by making pour plates of the mixture, the same number of fungi was recovered as was inoculated initially into the tissue suspension.

Blood cultures. Mice were anesthetized with ether and bled through the axillary artery. One $\mathrm{ml}$ of blood was inoculated onto the surface of $20 \mathrm{ml}$ of Sabouraud's agar in a $250 \mathrm{ml}$ flask. Colony counts were made at 7 and 14 days.

Observation period. When groups of mice were inoculated with $10^{4}$ to $10^{7}$ cells for determination of mortality rates, animals were observed for 26 to 40 days after initiation of infection.

Histological studies. Mice were sacrificed 30 minutes to 30 days after intravenous infection with $10^{5}$ to $10^{7}$ cells of $C$. albicans. Sections of brain, lung, heart, liver, spleen, adrenal, kidney, pancreas and skeletal muscle were studied. These were stained with Masson's trichrome stain or by the periodic acid-Schiff (PAS) technique.

Touch preparations of kidney, liver, lung and muscle

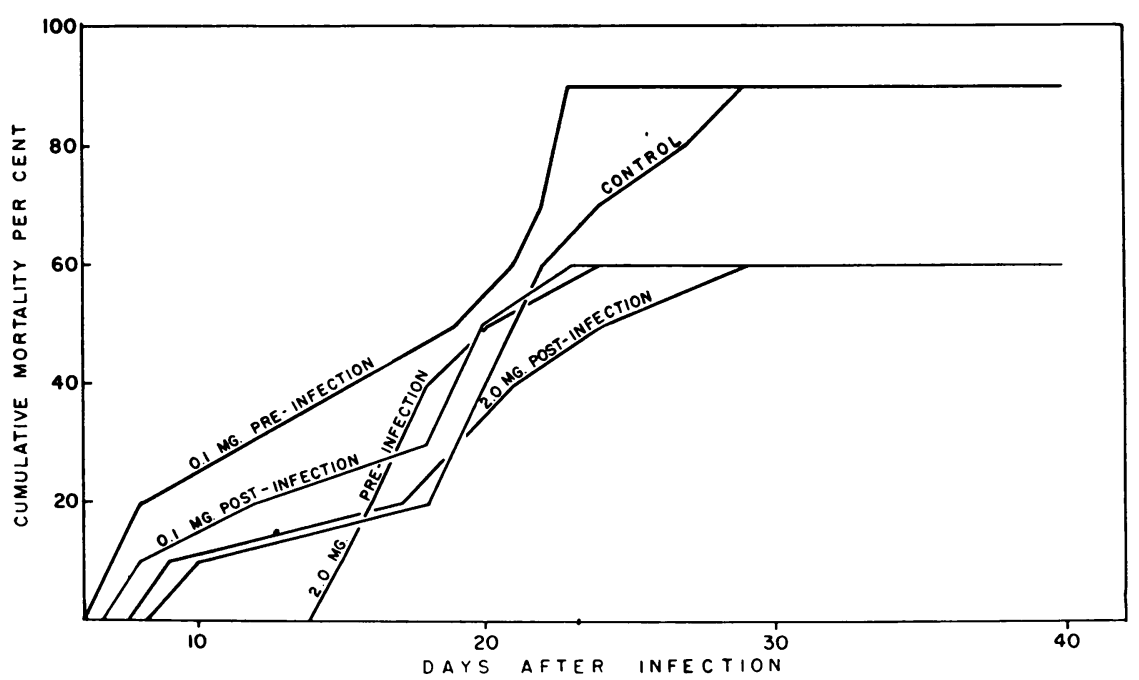

Fig. 2. EFFECT OF CORTISONE ON MORTALITY IN MiCE FOLlOWING I. v. INFECTION With $2 \times 10^{8}$ CELLS OF C. NEOFORMANS. Cortisone was administered intraperitoneally daily starting 6 days prior to (pre-infection) or the day following infection (postinfection) and was continued for 28 days after infection. 


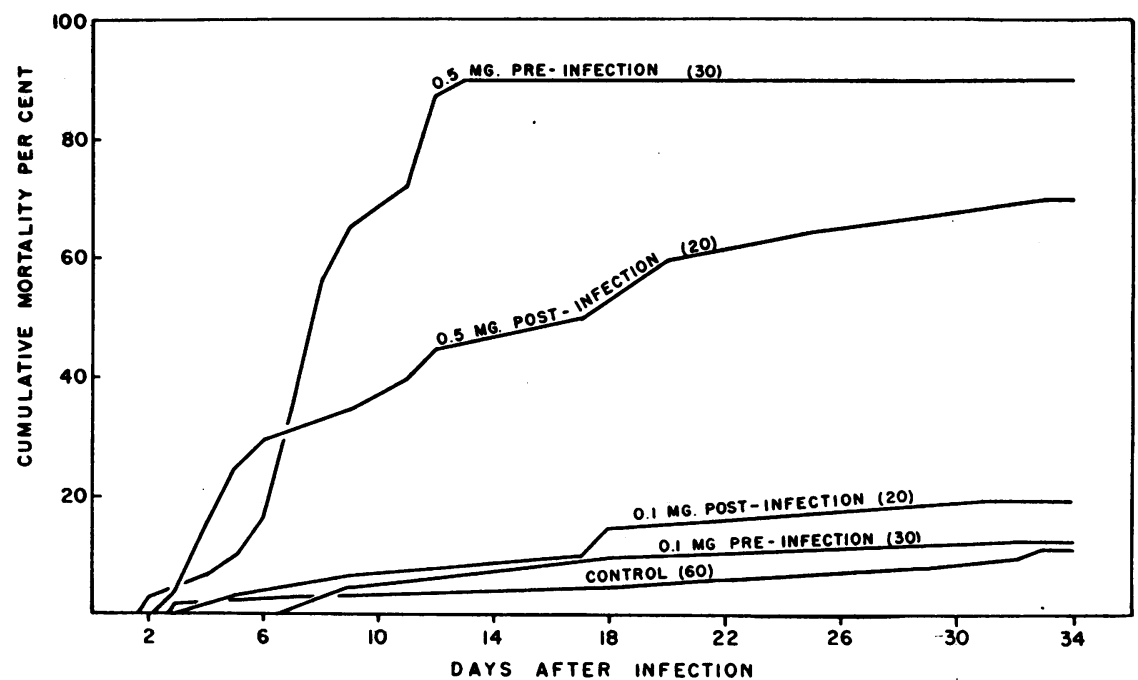

Fig. 3. EFFeCt OF CORTISONE ON MORTALITY IN MICE FOLLOWING I. V. INFECTION WITH $5 \times 10^{8}$ CELLS of $C$. ALBICANS. Cortisone was administered subcutaneously daily for nine days beginning two days prior to (pre-infection) or the day following infection (post-infection). Number of mice in each group is shown in parentheses.

lesions were made and were stained with Wright's stain or by the PAS technique.

\section{RESULTS}

Histoplasma capsulatum. The administration of 0.1 to $2.0 \mathrm{mg}$ daily of cortisone starting six days prior to or the day following infection did not alter the mortality or speed of death in mice infected with $10^{4}$ to $10^{7}$ cells of $H$. capsulatum.

Liver-spleen populations were studied in groups of 15 mice 15 days after infection with $3 \times 10^{1}$ cells. These were generally similar in cortisonetreated and control animals. These findings are depicted in Figure 1 which shows the mortality rates in an experiment in which animals were infected with the $10^{8}$ inoculum. The total mortality at each inoculum size in cortisone-treated and control mice is summarized in Table I.

Cryptococcus neoformans. No differences in mortality rates or rapidity of death were observed between cortisone-treated and control groups following infection with $2 \times 10^{4}$ to $2 \times 10^{8}$ cells. Liver-spleen census was studied 15 days after infection with $3 \times 10^{2}$ cells. Populations were similar in control and in cortisone-treated animals.

These findings are recorded in Figure 2 which depicts the results of an experiment in which animals were infected with an inoculum of $2 \times 10^{6}$ cells. The total mortality at each inoculum size in cortisone-treated and control mice is included in Table I.

Candida albicans. No increase in mortality was observed in cortisone-treated animals after infection with $10^{4}$ or $10^{5}$ cells. When the inoculum was increased to $10^{6}$, however, marked modification of the course of the infection was noted in the steroid-treated mice. Three of 30 controls (10 per cent) died during the 30 day observation period. Seven of 40 (17.5 per cent) which were given $0.1 \mathrm{mg}$ of cortisone daily died. Twenty-one of 60 mice ( 42 per cent) given 0.5 to $2.0 \mathrm{mg}$ of cortisone beginning prior to or one day following infection died during the observation period. The percentage of deaths in the group treated with the large dose of cortisone is significantly different statistically from the death rate in the control group according to the method of chi square $(\mathrm{p}=<0.05)$.

Increase in the inoculum to $5 \times 10^{6}$ produced more striking results. Eight of 70 controls (11.4 per cent) died of infection as did 11 of 70 mice (15.7 per cent) treated with $0.1 \mathrm{mg}$ of cortisone daily. In contrast, 59 of 70 (82.9 per cent) given the large dose of cortisone prior to or one day following infection died during the experimental period.

The experiments employing an inoculum of $5 \times 10^{8}$ cells per mouse are summarized in Figure 
3. It may be seen that the mortality rate was 90 per cent in mice given $0.5 \mathrm{mg}$ of cortisone two days prior to infection as compared to 70 per cent in animals in which treatment was begun one day after infection. These differences, however, are not statistically significant.

The over-all mortality observed during the experimental period at each inoculum size in normal and in steroid-treated animals is recorded in Table I.

The results of studies on the combined liverspleen-kidney populations of mice infected with $10^{5}$ cells supported the experiments on gross mortality rates.

Twenty-one of 25 control mice had small tissue populations at the time of sacrifice ranging from 0 to $3.0 \times 10^{2}$ per $\mathrm{ml}$. In the other four, fungus census was between $10^{4}$ and $10^{5}$ per $\mathrm{ml}$. Tissue census was not significantly different in mice given $0.1 \mathrm{mg}$ of cortisone.

In contrast. 24 of 25 mice given 0.5 to $2.0 \mathrm{mg}$ of cortisone had tissue fungus census which was greater than $10^{5}$ per $\mathrm{ml}$, and which in most titers was greater than $10^{6}$ per $\mathrm{ml}$. The differences between tissue populations in control mice and animals given the large dose of cortisone are highly significant $(p=<0.01)$.

Thus, the administration of large amounts of cortisone produced a marked increase in the mortality and tissue census following infection with $C$. albicans but did not enhance infections due to H. capsulatum or $C$. neoformans. The studies summarized below were then performed to delineate the site of maximum Candida infection in normal mice and to determine the effects of steroid administration on Monilia populations in the various organs.

Tissue census studies in normal mice infected with $10^{5}$ to $5 \times 10^{6}$ cells of $C$. albicans. Kidneys were studied in 186 animals, liver in 77. lungs in 49 , heart in 45 , brain in 38 and spleen in 20 . The kidney was the only organ in which progressive fungus multiplication was observed.

When $10^{5}$ cells were injected, kidney populations ranged from $8 \times 10^{2}$ to $5.3 \times 10^{3} 15 \mathrm{~min}$ utes after inoculation. No significant change was observed during the next 24 hours. Kidney fungus census increased more than tenfold above 2 standard deviations from the mean observed 15 minutes to 24 hours after infection in 8 of 56 mice, or approximately 14 per cent studied over the next 30 days. However, a progressive decrease was observed in the number of fungi recovered from the kidneys of most mice. In 13 of 21 animals studied 14 to 30 days after the initiation of infection no Candida was detected in renal homogenates.

When the inoculum was increased to $5 \times 10^{\circ}$ cells, kidney populations were somewhat higher initially, ranging from $5.8 \times 10^{4}$ to $1.6 \times 10^{5}$. Approximately 11 per cent of normal mice which were infected with this inoculum died, and in these animals there was evidence of progressive renal infection. In 7 of 61 survivors (11.5 per cent), sacrificed 7 to 30 days after inoculation, the number of Monilia in the kidneys had increased more than tenfold above 2 standard deviations from the mean census observed during the first 24 hours. Renal Candida populations in the other 54 animals tended to remain stationary during the first two weeks of infection, then fell in some animals so that 12 of 26 examined 30 days after infection demonstrated virtual clearance of the infection from the kidneys.

Bacteriological events in the other tissues studied were considerably different. Fungus populations were approximately tenfold greater in the liver immediately after infection. Monilia census did not change significantly in the liver, spleen, heart, lungs and brain during the initial 24 hours after inoculation, but then fell progressively in each of these organs, so that one week after infection populations were almost invariably small both in mice infected with $1 \times 10^{5}$ cells and in those inoculated with $5 \times 10^{6}$ cells. No fungi could be detected in these organs two weeks after infection.

In summary, there was evidence of progression of infection within the kidneys in 14 to 22.5 per cent of mice infected with $1 \times 10^{5}$ to $5 \times 10^{6}$ cells. No increase in tissue census was observed in the other organs studied. Clearance of the infection was also slower in the kidneys than in the other tissues examined.

Tissue populations in cortisone-treated mice infected with $1 \times 10^{5}$ cells of $C$. albicans. Cortisone was administered subcutaneously in daily dosage of $0.5 \mathrm{mg}$ beginning two days prior to infection and was continued for six days after the initiation of infection. The inoculum size of $10^{5}$ cells was chosen because it was the largest inoculum at 


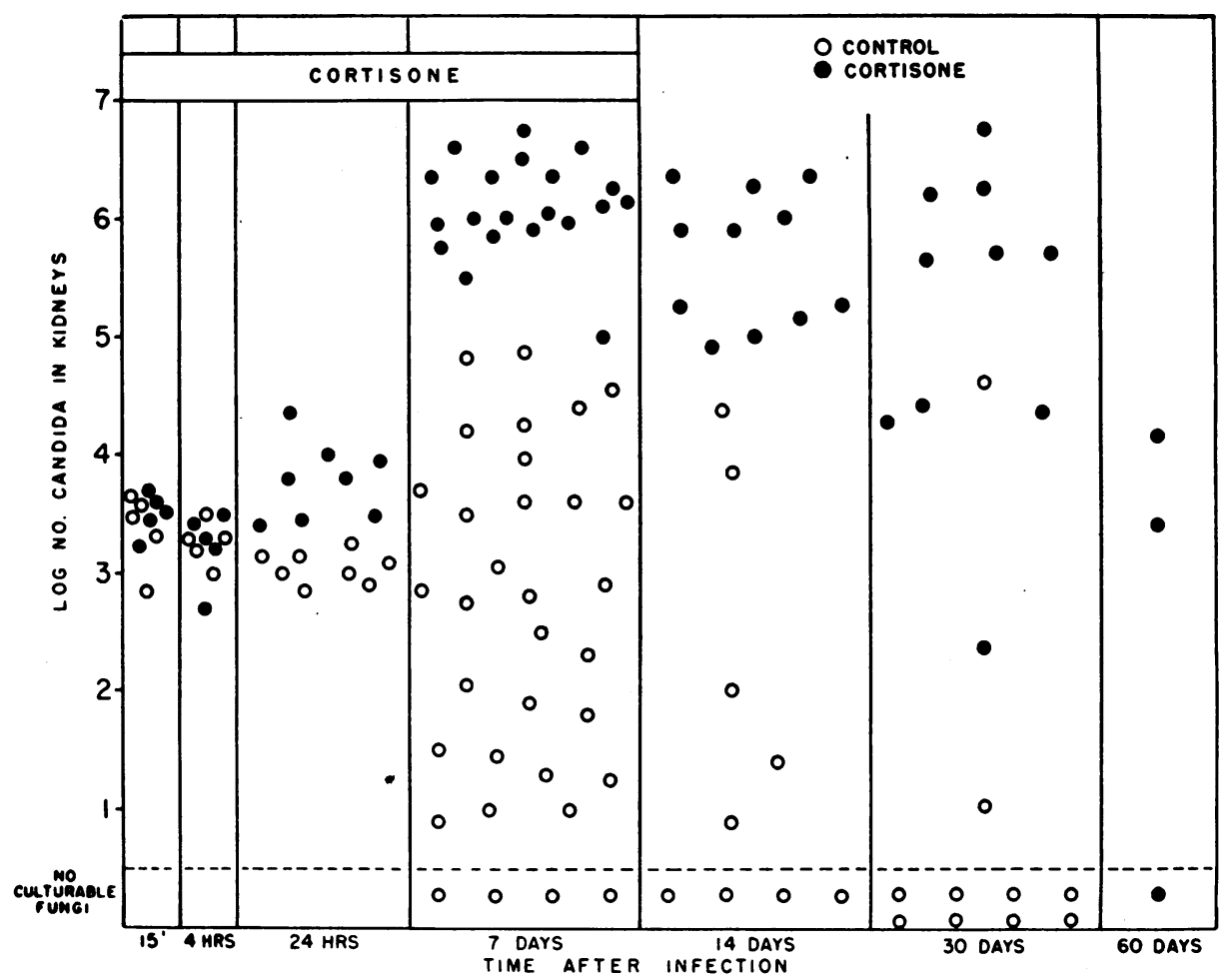

Fig. 4. THE EFFECT OF CORTISONE ON MOUSE KIDNEY POPULATIONS FOLLOWING INTRAVENOUS INFECTION WITH $10^{5}$ CELLS OF C. ALBICANS. Cortisone was administered subcutaneously daily in dosage of $0.5 \mathrm{mg}$ starting two days prior to infection.

which deaths from cortisone enhancement were rare. Thirty-day tissue population studies could, therefore, be performed readily.

Kidney populations were determined in 90 mice treated with cortisone over the 30 day period. Renal census was similar in control and in cortisone-treated mice 15 minutes to 4 hours after inoculation, and ranged from $5 \times 10^{2}$ to $5.2 \times$ $10^{3}$. Twenty-four hours after infection, populations were generally somewhat larger in steroidtreated mice. These differences are statistically significant at the 5 per cent level. Thereafter, cortisone-treated mice invariably demonstrated marked increase of infection within the kidneys. At the termination of cortisone treatment renal census ranged from $1 \times 10^{5}$ to $4.1 \times 10^{6}$. Kidney titers remained high seven days after stopping cortisone in all mice studied but diminished in four of ten animals examined 23 days after stopping steroid treatment.

These findings stand in striking contrast to the kidney populations observed in control mice. As indicated above, increasing kidney titers were ob- served in only 14 per cent of animals infected with $1 \times 10^{5}$ cells and in most mice there was a progressive decrease in the numbers of Monilia in the kidneys. These studies are summarized in Figure 4.

Bacteriological events were markedly different in the liver, lungs, heart, spleen and brain. Populations were similar in cortisone-treated and control mice 15 minutes to 24 hours after infection. Candida clearance was delayed in mice treated with cortisone. Thus, Monilia census at the termination of steroid treatment was commonly similar to that observed immediately after the initiation of infection. In no animal, however, was there evidence of progression of infection within the liver, spleen, lungs, or brain, and in each of these tissues the fungus was rapidly cleared as soon as cortisone treatment was stopped. These findings are shown in Figure 5 in which the effects of cortisone on liver and lung populations are summarized, the results being similar in the spleen and brain.

Candida census rose more than 2 standard deviations above mean values observed during the first 
24 hours of infection in 2 of 40 hearts. In the other 38 mice, clearance was delayed during cortisone administration but no progression of infection was observed.

Studies on moribund animals dying within the first week of infection. The studies detailed above indicated that cortisone enhancement of moniliasis in mice was usually associated with increase in infection only in the kidneys. In an effort to see if fungus multiplication could be induced in other organs, mice were infected with $5 \times 10^{6}$ cells and were sacrificed for tissue population studies if they became moribund during the first 7 days of infection. Cortisone regimens in these studies consisted of $0.5 \mathrm{mg}$ daily, starting two days prior to infection and continuing until sacrifice, or $2.5 \mathrm{mg}$ the day prior to, the day of, and the day after infection.

The results of these studies are depicted in Figure 6 in which populations observed when mice were moribund are compared with populations found 4 hours after infection.

Kidney populations 4 hours after infection varied from $4.8 \times 10^{4}$ to $3.0 \times 10^{5}$ and rose to $7.84 \times 10^{8}$ to $1.7 \times 10^{8}$, the average increase being 500 -fold.

Heart census ranged from $2.3 \times 10^{4}$ to $3 \times 10^{5}$ 4 hours after infection and increased to $9 \times 10^{4}$ to $3 \times 10^{6}$ when mice were terminally ill. The mean increase was 17 times the 4 hour titer. Lung populations varied from $2.2 \times 10^{4}$ to $1.2 \times 10^{5} 4$ hours after inoculation. The numbers of Candida in the lungs of moribund mice ranged from 3.54 $\times 10^{4}$ to $2.8 \times 10^{5}$, the average increase being only fourfold.

Liver census 4 hours after infection varied from $2 \times 10^{5}$ to $6 \times 10^{5}$. Populations in moribund mice had increased an average of 2.5 times and ranged from $8.4 \times 10^{4}$ to $2.16 \times 10^{6}$.

Brain census varied from $3.3 \times 10^{4}$ to $5.8 \times 10^{4}$ 4 hours after infection and ranged from $3.1 \times 10^{4}$ to $8 \times 10^{5}$ when animals were terminally ill, an average rise of fivefold.

Thus, even in mice dying rapidly of overwhelming candidiasis, cortisone enhancement was limited almost exclusively to the kidneys. Liver, lung and brain populations showed only a minimal increase and heart census rose moderately. Whether the

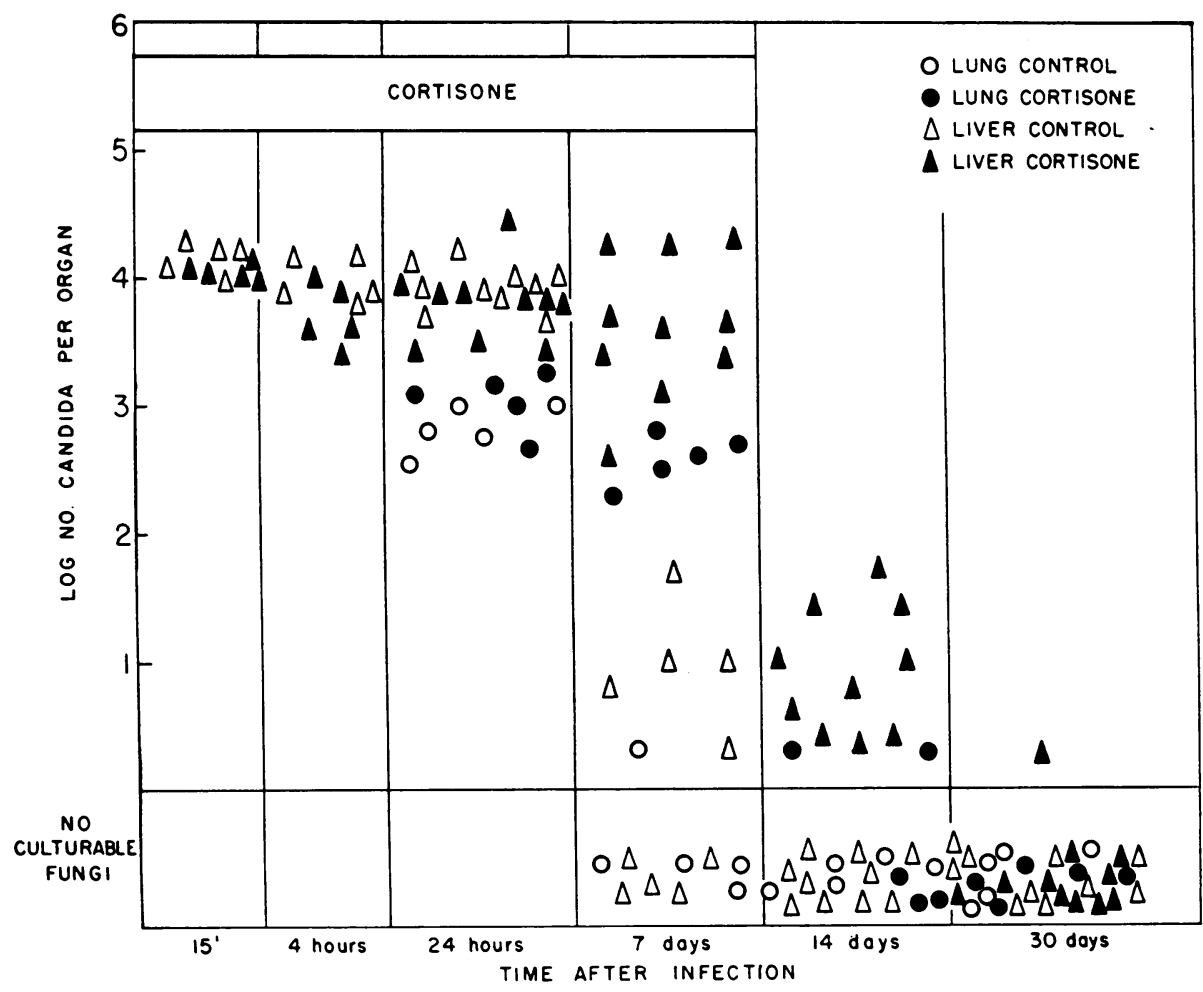

Fig. 5. EFfect of CORTisone on liver and Lung populations in mice infeCted I. v. With $10^{5}$ CELLS of C. ALBICANS. Cortisone was administered subcutaneously in dosage of $0.5 \mathrm{mg}$ per day starting two days prior to infection. 


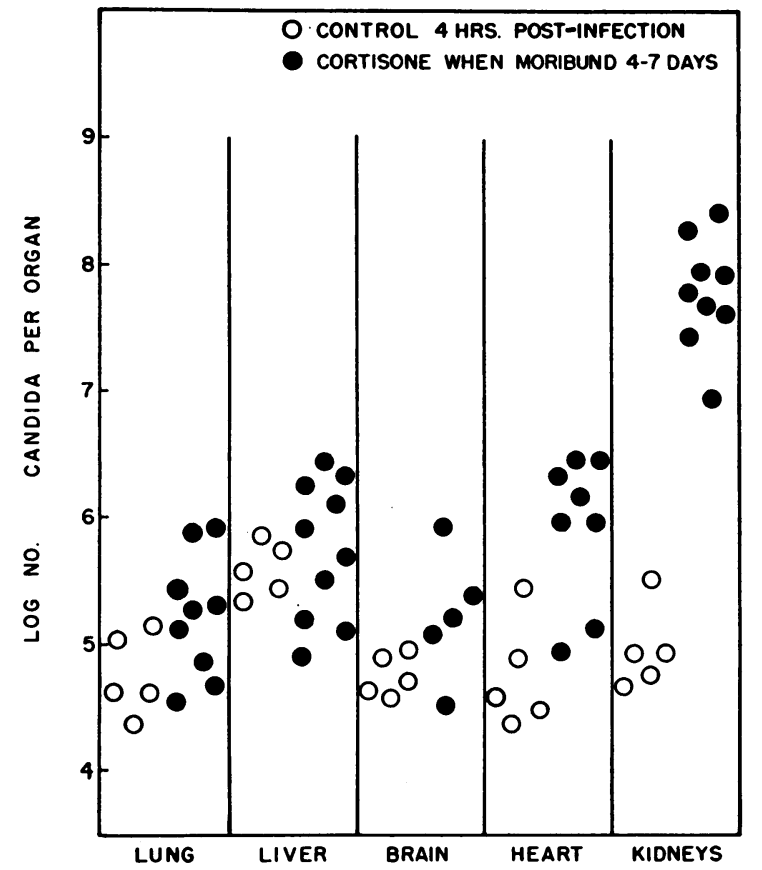

Fig. 6. TISSUE POPUlations in CORTISONE-TREATED MORIBUND ANIMALS DYING DURING THE FIRST SEVEN DAYS OF INFECTION WITH $5 \times 10^{6}$ CELLS OF $C$. ALBICANS.

small increases in heart, lung, liver and brain census actually represented multiplication of the fungus within these tissues was uncertain, since moribund mice invariably demonstrated fungemia which ranged from 20 to 300 cells per $\mathrm{ml}$ of blood.

Effect of delaying cortisone treatment. The effects of cortisone were markedly reduced when treatment was delayed. When the hormone was administered prior to infection with $5 \times 10^{6}$ cells, 27 of 30 mice ( 90 per cent) died during the observation period. When treatment was begun the day after infection mortality was slightly diminished, 14 of 20 (70 per cent) animals dying with:n 30 days (see Figure 3 ). Delay in starting cortisone until 1 week after infection further reduced the mortality to 3 of 17 mice ( 17.2 per cent). This latter figure was not significantly different from the 11.7 per cent death rate observed in control mice infected with $5 \times 10^{6}$ cells.

An analysis of tissue populations confirmed the studies on mortality rates. When $0.5 \mathrm{mg}$ cortisone was administered prior to infection with $10^{5}$ to $5 \times 10^{6}$ cells, the average rise in renal census during the initial seven days of infection was 1,495 fold. Delay until the infection was established for 24 hours decreased the extent of enhancement so that kidney populations rose only an average of 386 times the mean census observed immediately after infection.

If cortisone was withheld until the infection was seven days old the effects of the steroid were reduced further, the mean increase in renal census being only 49 -fold. Thus, the time of administration of cortisone appeared to be of major importance in the degree of augmentation of infection.

The effects of cortisone in mice challenged with small inocula of $C$. albicans. Infections due to $C$. albicans in man are probably initiated with small numbers of fungi. It seemed important, therefore, to determine whether cortisone could significantly increase tissue populations under experimental conditions in which the infecting inoculum was small.

Two experiments were performed in which mice were infected with $10^{3}$ cells and were treated with $0.5 \mathrm{mg}$ cortisone daily beginning two days prior

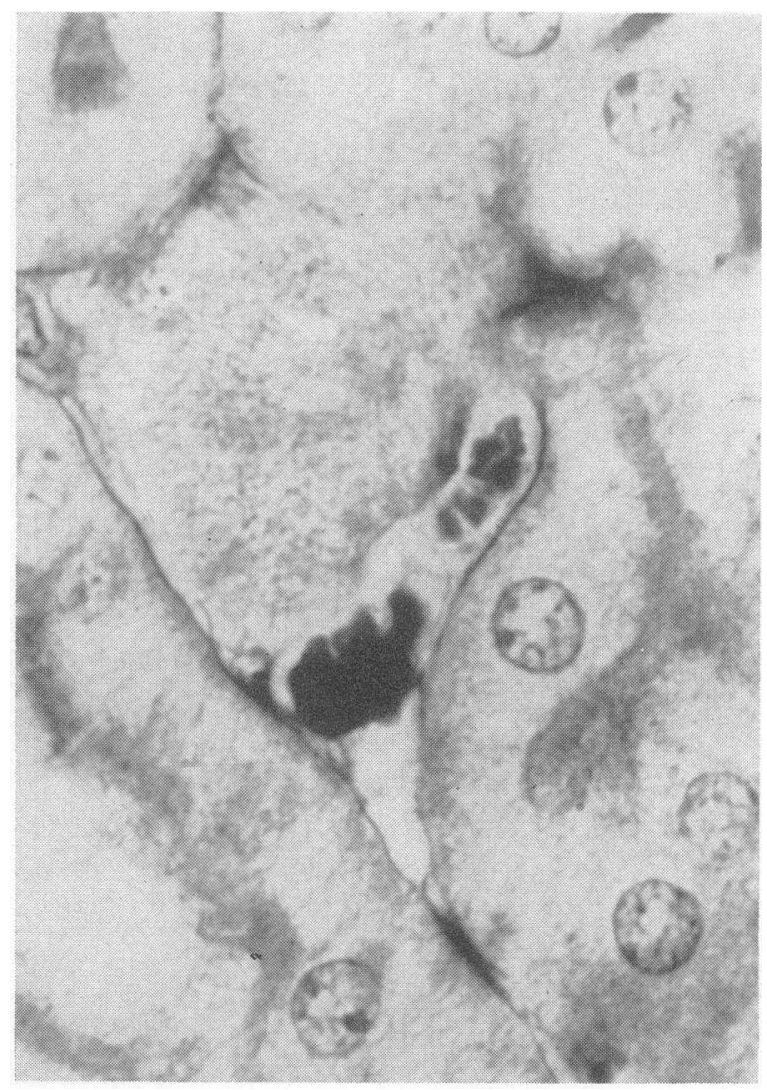

Fig. 7. Budding Form of $C$. ALBICANS SURRounded By NEUTROPHILS IN A CORTICAL CAPILLARY OF THE KIDNEY OF A CORTISONE-TREATED MOUSE 6 HOURS AFTER I. V. INOCULATION WITH $10^{7}$ ORGANisms. ( $\times 2,100$; PAS-hematoxylin.) 


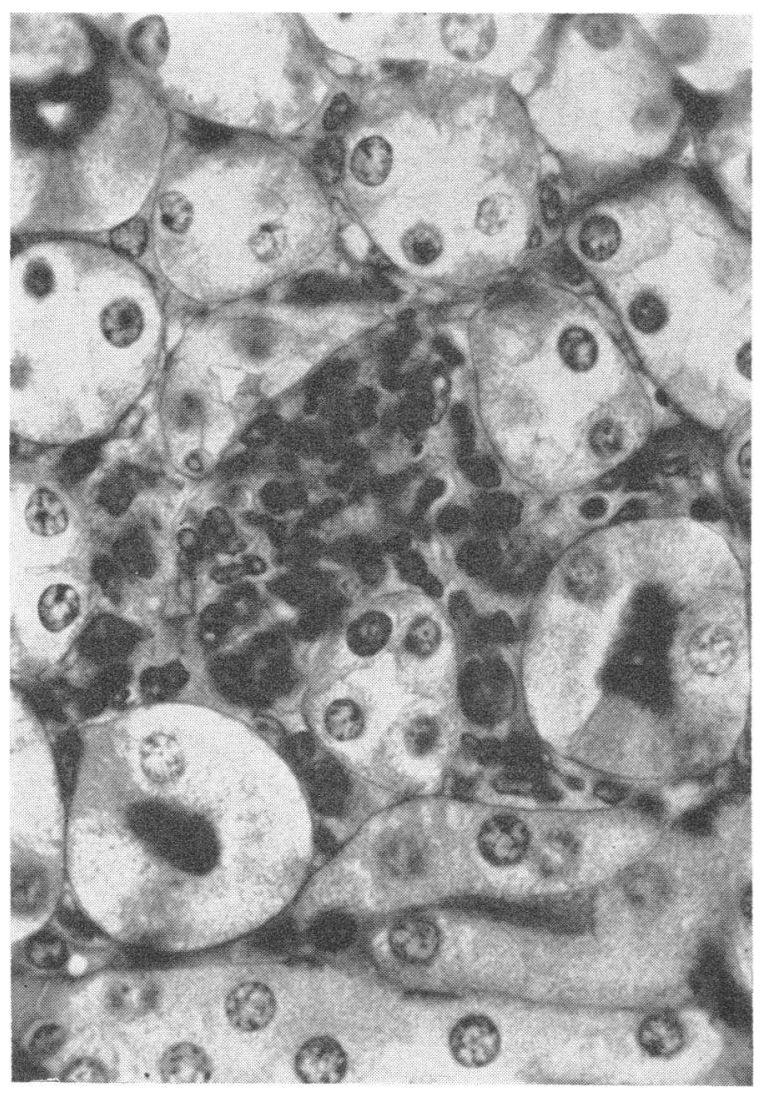

Fig. 8. Interstitial Lesion (Microabscess) in the CORTEX OF A KIDNEY OF A CORTISONE-TREATED MOUSE 24 HOURS AFter I. v. IN Jection With $10^{7}$ ORganisms. Proliferating fungi are surrounded by polymorphonuclear leukocytes. The inflammatory cells and fungi in the expanding lesion compress the surrounding tubules. $(\times 1,200$; PAS-hematoxylin. $)$

to infection and continuing for nine days. Renal census was determined at the termination of cortisone treatment.

Kidney populations varied from 0 to $3 \times 10^{1} 4$ hours after infection. Seven days after infection renal census was less than $10^{1}$ in 8 of 10 control animals and less than $10^{3}$ in all 10 . On the other hand kidney populations were greater than $10^{3}$ in 7 of 11 cortisone-treated animals and were greater than $10^{5}$ in 5 of these 7 . There was then clear evidence that cortisone could cause marked increase in infection even if the inoculum was small.

Histological studies on normal mice. The initial lesions were similar in all tissues following intravenous inoculation. Fungal spores were trapped in the capillaries of the lungs, liver, spleen, heart, pancreas, adrenals, skeletal muscle and kidneys.
Touch preparations showed that as early as 0.5 hour after injection, neutrophils, and macrophages had phagocytized some spores. Others were found free within the capillaries as late as 24 hours after inoculation.

Four hours after infection, budding and hyphal forms, often surrounded by neutrophils, had begun to appear within the vessels (Figure 7). As growth continued, the hyphae broke through the capillary wall into the interstitial tissues. Thereafter, necrosis occurred, and this was accompanied by a more intense cellular response, which reached a peak in from 24 to 30 hours with formation of frank abscesses (Figure 8). Micro-abscesses occurred in the liver, kidney, pancreas, heart and skeletal muscle, but only rarely in the lungs, and never in the spleen or adrenals.

In all organs except the kidneys, the lesions invariably regressed. By the third day, they were

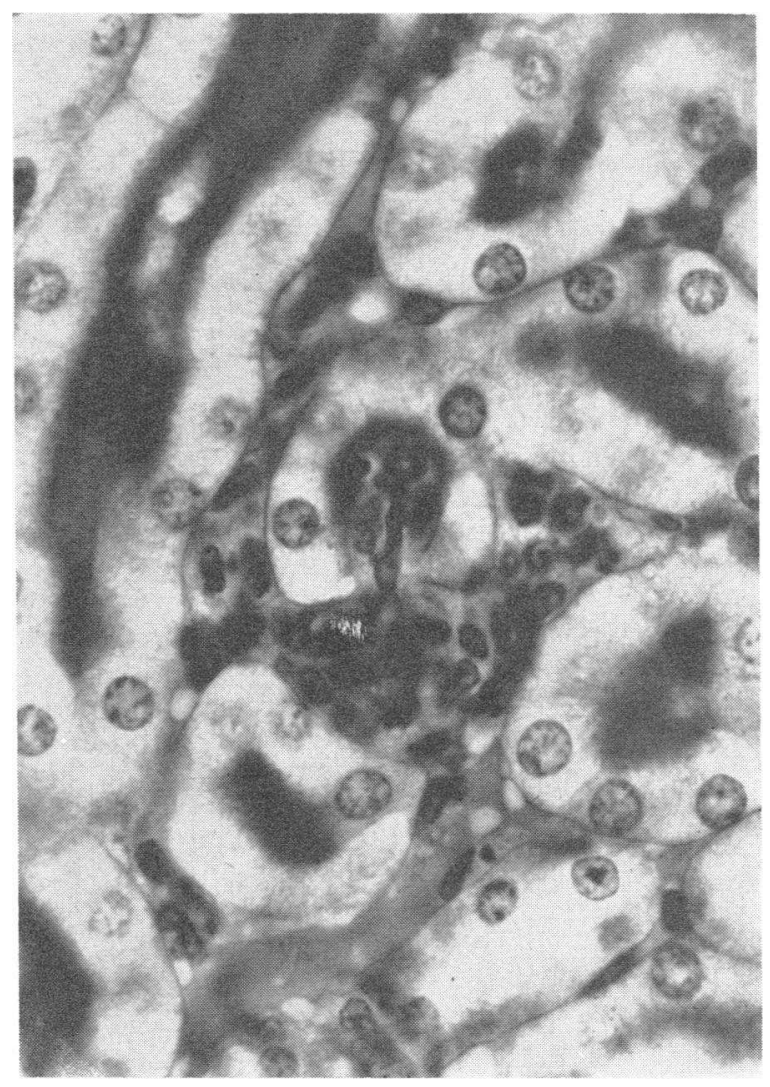

Fig. 9. A growing hiYphal FORM OF C. ALbiCANS RUPTURING INTO THE LUMEN OF A PROXIMAL CONVOLUTED TUBULE IN THE KIDNEY OF A CORTISONE-TREATED MOUSE 24 HOURS AFTER INOCULATION WiTH $10^{7}$ ORGANiSMS. $(\times 1,200 ;$ PAS-hematoxylin. $)$ 
generally inapparent or marked by small accumulations of histiocytes, in which fungi were seldom seen.

In the kidneys the interstitial lesions also commonly regressed, but progression of the lesions was occasionally observed. Such progression was associated with rupture by the fungus through the walls of both cortical and medullary tubules or glomerular tufts into the lumina of the nephrons (Figure 9).

Once within the lumen of the tubule the fungi multiplied rapidly and grew proximally and distally (Figure 10) forming long hyphal elements. Growth in this apparently protected site was not associated with the inflammatory response which was so prominent in the interstitium. Polymorphonuclear leukocytes were carried into the tubules with the fungi. These became pyknotic and

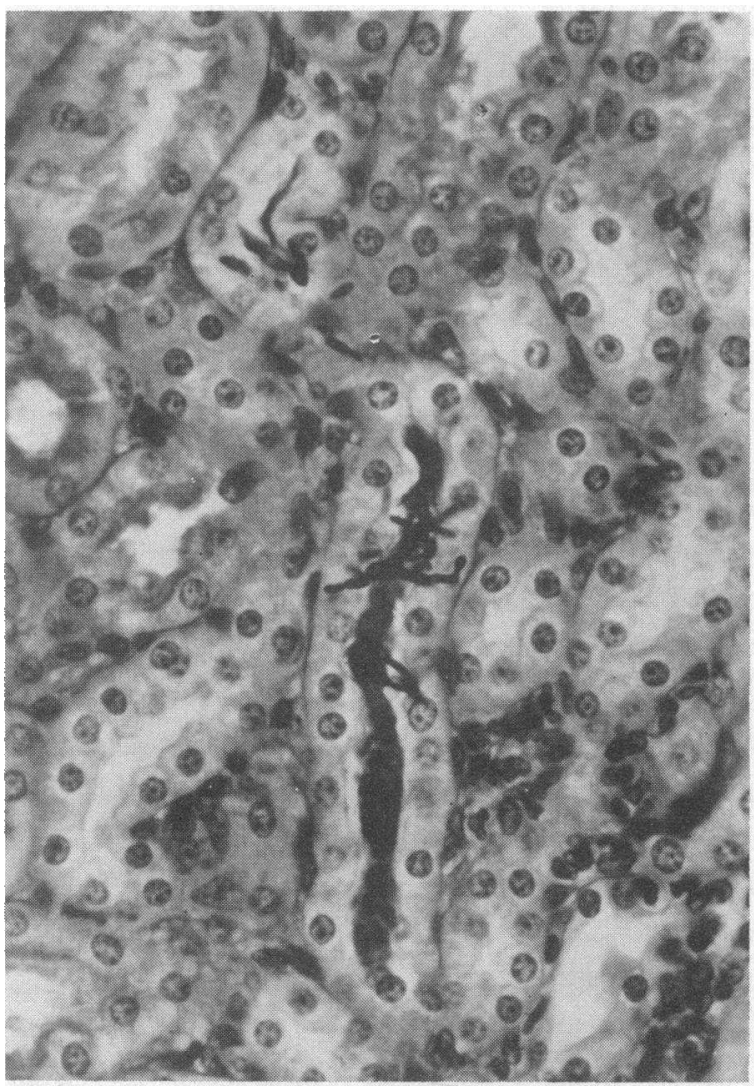

Fig. 10. Rapid intratubular growth of $C$. ALBICANS WITHIN THE LUMEN OF A DISTAL CONVOLUTED TUBULE OF THE KIDNEY OF A CORTISONE-TREATED MOUSE 24 HOURS AFTER I. V. INOCULATION WITH $10^{7}$ ORGANISMS. Growth within the tubule is unaccompanied by polymorphonuclear leukocytic response. ( $\times 675$; PAS-hematoxylin.) karyorhectic. No further polymorphonuclear infiltration occurred during this stage in the development of the lesion, despite the extensive intraluminal multiplication of Monilia.

Mycelial casts with or without necrotic polymorphonuclear leukocytes were washed into the medulla and were caught in the loops of Henle or collecting tubules. There the fungi continued to grow rapidly and, as in the lumina of the cortical tubules, at first without cellular response.

Within 24 hours of the time of inoculation, however, many of the large hyphae growing within the tubules had once more broken out into the interstitium and adjacent nephrons. The reappearance of the fungus in the interstitium was associated with an intense inflammatory response. This time the larger hyphal elements formed the foci of much more intense and destructive cortical and medullary abscesses than had been produced when the growing spores first penetrated the capillary wall.

In the occasional control animal in which this type of progressive lesion developed, but which nevertheless survived beyond the third day after infection, the large cortical abscesses regressed. The lesions became localized by the accumulation of many macrophages and proliferating fibrous tissue at their peripheries. The hyphae and spores were ingested by the macrophages, became fragmented, lost their staining characteristics, and gradually disappeared. By 14 days after inoculation, such lesions were only identified by cellular scars in the cortex.

Pathogenesis of the lesions in cortisone-treated mice. Early lesions caused by the fungus were similar to those described in control animals. By the methods used, polymorphonuclear infiltration and phagocytosis appeared to occur with equal rapidity in cortisone-treated and control mice. The subsequent lesions observed 4 to 48 hours after infection were more florid and more numerous, however, in all organs examined in the mice treated with cortisone. The interstitial abscesses in the liver, kidney, pancreas, heart, and skeletal muscle had by 24 to 48 hours reached greater dimensions. They contained more neutrophils and fungi, either viable or disintegrating, and involved the destruction of more parenchymal cells.

The renal lesions invariably progressed. Rupture of the fungus into the tubular lumen occurred far more extensively than in control animals, and 


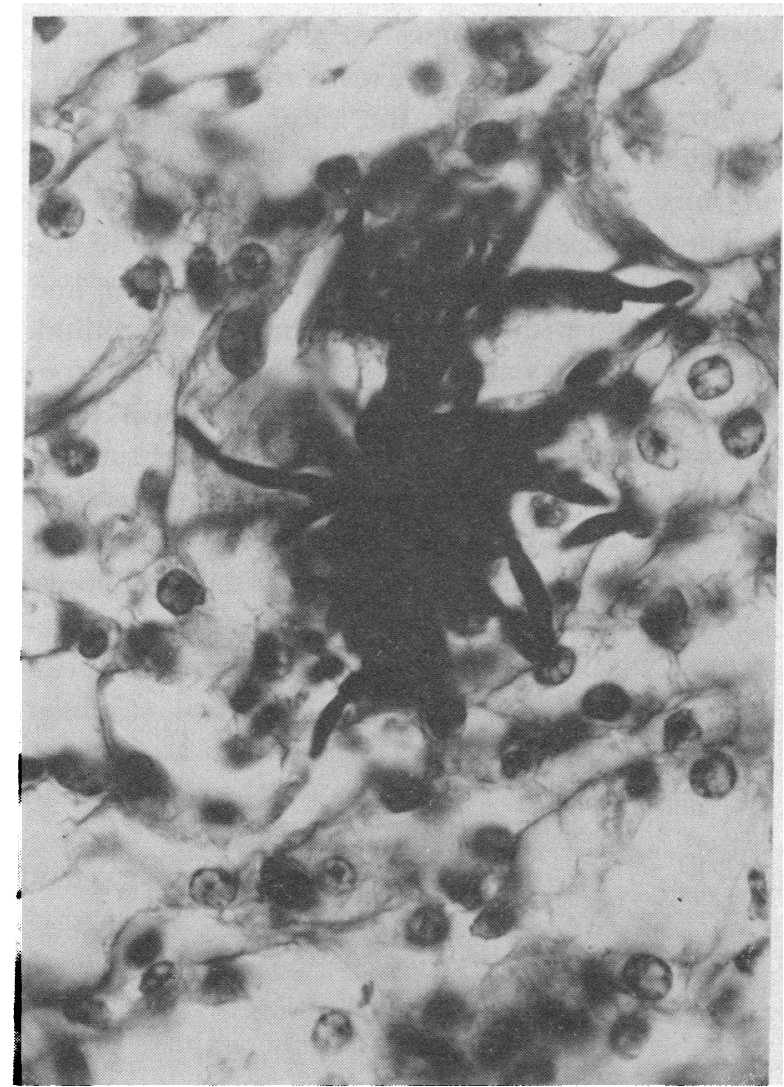

Fig. 11. A KNOT OF PROLIFERATING HYPHAE BREAKING FROM THE LUMEN OF A COLLECTING TUBULE INTO THE INTERSTITIAL TISSUE OF THE RENAL MEDULLA OF A CORTISONE-TREATED MOUSE 24 HOURS AFTER I. V. INOCULATION WITH $10^{7}$ oRGANISMS. $(\times 1,200$; PAS-hematoxylin. $)$

was followed by rapid intratubular growth unassociated with intratubular inflammatory response. Within 24 hours, the fungi growing within tubules had again penetrated the tubular walls to break back into the interstitium. Polymorphonuclear response to this recurrent interstitial invasion was intense with the production of large destructive cortical and medullary abscesses. The burgeoning mycelial knot that developed from the rapid intratubular growth of the fungi and then broke out into the interstitium appeared much less susceptible to phagocytosis than did the yeast cells and the isolated pseudomycelial growths that had broken into the tubules (Figure 11).

In the kidneys of cortisone-treated mice at 24 hours, then, there was a large number of cortical and medullary abscesses, as well as a smaller number of blood-borne interstitial lesions and proliferating intratubular casts in the medulla.
By the third day, and thereafter until the seventh day, retrograde and lateral spread of these lesions led to the production of subcapsular granulomas and infarct-like lesions (Figure 12). Large masses of mycelia grew from the papillae into the calyces. Parenchymal abscesses took the form characteristic of mycetomal lesions with a central mycelial knot surrounded by a wide zone of polymorphonuclear leukocytes and a periphery of macrophages, lymphocytes, fibroblasts, and occasional giant cells.

From the third to the seventh day new lesions appeared in the kidneys of the cortisone-treated mice but not in those of the control mice. Discovery of eroded walls of veins at the periphery of abscesses in steroid-treated animals suggested

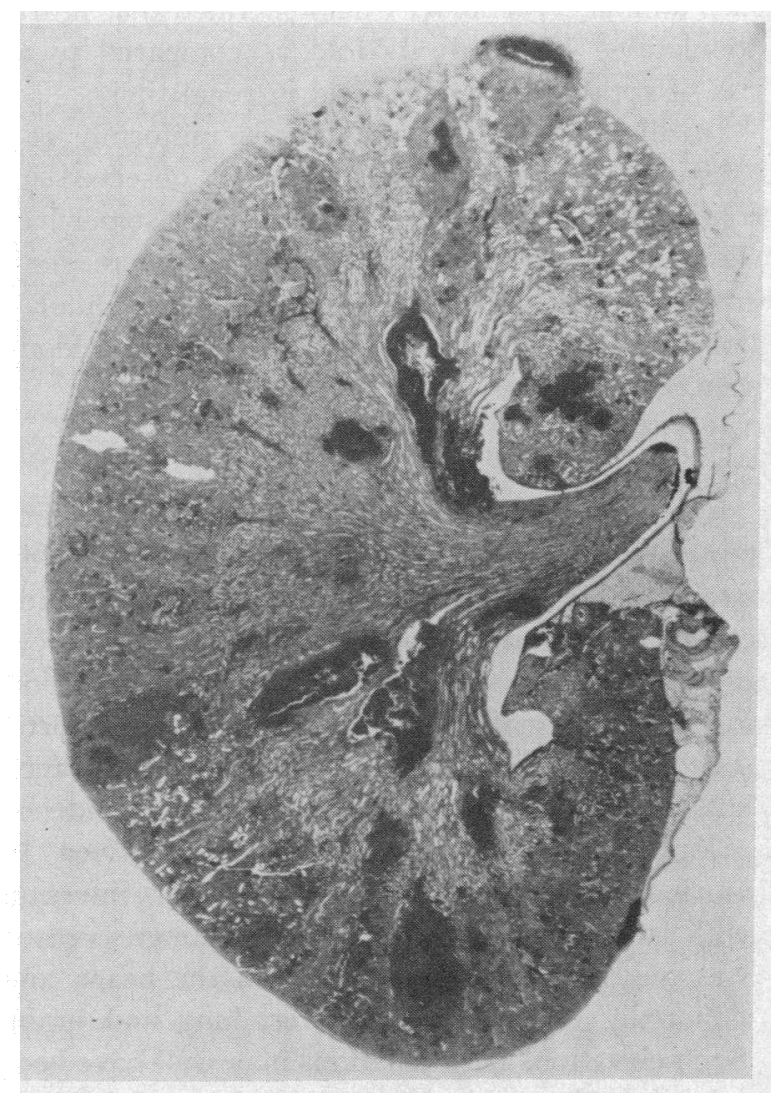

Fig. 12. MUltiple Lesions IN THE KIDNEY OF A CORTISONE-TREATED MOUSE 7 DAYS AFTER I. V. INOCULATION WITH $10^{5}$ ORGANISMS. Large mycelial masses (black areas) are surrounded by an inner zone of polymorphonuclear leukocytes and by an outer zone of macrophages and fibroblasts. Wedge-shaped, infarct-like lesions are distributed throughout the cortex. Fungi grow from the parenchyma of the medulla into the lumen of the pelvis. ( $\times 12$; PAS-hematoxylin.) 
a means by which the continued dissemination of the infection took place.

In the mice that survived after the seven to nine day period of cortisone administration, there was gradual resolution of the lesions and replacement of destroyed renal parenchyma by scar tissue.

The only other tissue besides the kidney in which extensive lesions were observed was heart muscle. Here the lesions in cortisone-treated mice usually regressed in a similar fashion to that in control mice. However, in some of the steroidtreated mice, which were sacrificed when moribund five to seven days after infection, myocardial abscesses which contained many fungi had developed, and caused destruction of much myocardium. Simultaneous tissue census studies on such animals (see above) demonstrated that heart populations rose only 17 -fold as compared to a rise of approximately 500 -fold in renal titers.

In all other tissues, the lesions uniformly regressed in a fashion similar to that observed in control animals, although healing was somewhat slower. By the third day the lesions were generally unapparent or marked by small accumulations of histiocytes in which fungi were seldom seen.

\section{DISCUSSION}

These studies suggest that the increased mortality in cortisone-treated mice infected with this strain of $C$. albicans was related specifically to increased multiplication of the fungus in the kidney, the organ which is the site of maximum infection in normal animals. In extra-renal tissues, cortisone treatment commonly delayed fungus clearance but only rarely (in the heart) was there evidence of increase in Candida populations. Even in moribund animals dying rapidly after infection with large numbers of $C$. albicans, fungus census was only moderately increased in the heart, and minimally elevated in the liver, lung and brain. Such elevations in populations may well have been related to the marked fungemia observed in these animals.

The kidney is the site of maximum multiplication in numerous other experimental infections, including those due to staphylococci (19), Mycobacterium fortuitum (20), and Corynebacterium renale (21). The mechanisms underlying the renal susceptibility to infection have not been de- lineated. The histological studies detailed above offer a plausible explanation for the localization of progressive infection to the kidneys in both normal and cortisone-treated mice infected with $C$. albicans.

The initial cellular response to invasion of the kidneys by Candida was polymorphonuclear and occured both within vessels and in the interstitium. Within 24 hours after infection, fungi broke from the interstitium apparently by mechanical pressure into the cortical and medullary renal tubules. Blyth (22), and Evans and Winner (23), in studies on normal animals, have also observed the growth of pseudomycelia into tubular lumina. Once within the tubular lumen, the fungus appeared protected from host defenses and grew rapidly forming long hyphal elements. Cellular defenses of the host did not appear to be effective until these hyphae again broke through the tubule wall back into the interstitial tissues.

The extent of intratubular growth appeared to determine the outcome of infection. When normal mice were given large inocula, intratubular multiplication and subsequent abscess formation were commonly limited, and the animal usually survived. In cortisone-treated animals injected with such inocula, intratubular growth was massive. This was followed by marked abscess formation and death.

In contrast to the events described in the kidney, histological study of other tissues revealed regression of lesions 24 to 72 hours after infection in control and cortisone-treated mice. Extensive extra-renal lesions were found only in the hearts of moribund animals dying four to seven days after infection with $5 \times 10^{6}$ cells.

The apparent ability of $C$. albicans to evade host defenses by intratubular residence would appear to be analogous to the protection afforded other microbes by an intracellular habitat. Thus, for example, Rogers showed that staphylococci incorporated into polymorphonuclear leukocytes were far better able to withstand passage through reticuloendothelial organs than were staphylococci which remained extracellular (24).

The hypothesis offered here that the renal localization of Candida infections in normal and cortisone-treated animals is related to the protection offered the fungus by intratubular residence has not been invoked before to explain the suscep- 
tibility of the kidney to experimental or clinical infections. Whether intratubular growth may also account for renal localization of infections other than moniliasis is not known. The evidence presently available, however, suggests that different mechanisms may be of far greater importance in certain infections. Studies by Freedman and Beeson (25) have demonstrated that the renal medulla is more susceptible to Escherichia coli infections than is the renal cortex. Recent studies by Beeson and Rowley (26) suggest that the medullary susceptibility may be related to local inactivation of serum bactericidins by ammonia. It seems unlikely that such a mechanism is of major significance in moniliasis. The localization of fungal cells can be determined readily by histological studies of the kidney. There is no medullary predilection in Candida infections. Studies in our laboratory, which will be described in detail subsequently, demonstrate no inhibitory effect of mouse serum or plasma on $C$. albicans.

Although serial determinations of Monilia populations in several extra-renal tissues including lungs, liver, spleen, heart and brain demonstrated no increase in the number of recoverable fungi in mice treated with cortisone over the initial 24 hours of infection as compared with control animals, simultaneous histological studies showed clear evidence of increased growth of the fungus and augmented infiltration by neutrophils during this period. The enhanced infiltration by leukocytes appeared to be an appropriate reaction to the increased multiplication of the fungus. The early events in the kidney were similar to those observed in other tissues. Increased Candida multiplication within vessels and in the interstitial tissues was associated with a more prominent cellular infiltrate.

Failure of the bacteriological studies to demonstrate the increased growth observed microscopically suggests the possibility that the increased growth of Candida was balanced by increased destruction of the fungus. It is also possible that small increases in the number of Candida cells may not have been detectable by the quantitative enumeration techniques employed. Progressive infection failed to develop in extra-renal organs despite the early generalized increase in multiplication of fungi under the influence of cortisone and it seems that this may well be related to the in- ability of the fungus to find a site for protected growth within these tissues.

The time of administration of cortisone appears to determine the degree of enhancement of experimental Candida infections. Delay in steroid administration until 24 hours after infection with $5 \times 10^{6}$ cells decreased the mortality from 90 to 70 per cent. Further delay in initiation of cortisone treatment until seven days after infection markedly reduced the effects of the steroid so that the mortality was not significantly different from that noted in control animals, and only a modest increase in renal Candida census was observed. These studies are then in agreement with experiments on other microorganisms which indicate that the effects of steroids are reduced markedly if treatment is withheld until host defenses are established $(27,28)$.

Under the conditions of the present experiments, Candida infections were clearly enhanced to a far greater degree than infections due to $H$. capsulatum or $C$. neoformans. These findings do not necessarily contradict previous work demonstrating enhancement of experimental histoplasmosis or cryptococcosis by adrenal steroids (2-6). In the studies herein reported, experiments on $H$. capsulatum and $C$. neoformans were performed on $\mathrm{NIH}$ mice. It has been emphasized that the strain of animal used may influence to a great extent the results of studies on the effects of cortisone on a particular infection (29). It seems quite possible that the use of certain mouse strains would have been associated with augmentation not only of candidiasis but also of histoplasmosis and cryptococcosis. Indeed, limited experiments in this laboratory with CFW strain mice have demonstrated significant enhancement of cryptococcosis under the influence of cortisone. Nevertheless, the demonstration of differences among the three fungi in the degree of enhancement of infection by steroids under certain experimental conditions suggests that similar alterations induced by cortisone in the host may clearly favor the establishment of microbial parasitism by some mycotic species rather than by others. It is conceivable that these studies may offer a partial explanation for the well documented observation that the administration of adrenal hormones to man is associated with the appearance of disseminated moniliasis far more often than histoplasmosis or cryptococcosis 
despite the frequent presence of the latter two fungi in the exogenous and, in the case of $C$. neoformans, in the endogenous environment of man.

It is important to emphasize that marked increase in renal Candida populations were noted in most cortisone-treated animals even when the infecting inoculum was small. One of the difficulties in applying experimental knowledge to human infection is the necessity for using very large inocula in the experimental study of microorganisms of low pathogenicity such as Monilia. Human infections on the other hand are probably initiated with small numbers of microorganisms. Since cortisone produces marked enhancement of Candida infections initiated with small inocula, and since the kidney is the organ of maximum infection in both man and mouse (30), there is a considerable possibility that the experimental findings herein described may contribute to an understanding of some cases of disseminated moniliasis in man.

\section{SUMMARY}

Experimental Monilial infections in mice were enhanced to a far greater degree by cortisone than were infections due to Histoplasma capsulatum or Cryptococcus neoformans.

The kidney was demonstrated to be the only tissue in which progressive infection occurred in normal mice following intravenous injection of Candida albicans. The administration of cortisone was associated with striking enhancement of the renal infection. Tissue Candida clearance was delayed in extra-renal sites during cortisone treatment but increase in Monilial census was observed only rarely (in the heart).

Histological studies suggested that the renal localization of infection in normal and cortisonetreated mice was related to rupture of the fungus into tubular lumens. Once within the tubule the fungus appeared protected from host defenses and grew in an uninhibited fashion. Extensive intratubular residence was uncommon in normal mice injected with $10^{5}$ to $5 \times 10^{6}$ cells but occurred uniformly in cortisone-treated animals.

Enhancement of renal infection was also observed in most cortisone-treated animals injected with small inocula. The maximum effect of cortisone was produced when animals were given treatment from two days prior to infection. Delay in the initiation of cortisone treatment until the day after infection reduced the effects of the hormone. When cortisone was administered beginning seven days after infection no significant enhancement was observed.

\section{REFERENCES}

1. Kass, E. H., and Finland, M. Adrenocortical hormones in infections and immunity. Ann. Rev. Microbiol. 1953, 7, 361.

2. Levine, S., Zimmerman, H. M., and Scorza, A. Experimental cryptococcosis (torulosis). Amer. J. Path. 1957, 33, 385.

3. Königsbauer, $H$. Über die Wirkung von Corton auf die experimentelle Torulose und Chromoblastomycose. Zbl. Bakt., I. Abt. Ref. 1954, 160, 637.

4. Farrell, R. L., Cole, C. R., Prior, J. A., and Saslaw, S. Experimental histoplasmosis. I. Methods for production of histoplasmosis in dogs. Proc. Soc. exp. Biol. (N. Y.) 1954, 84, 51.

5. Mankowski, Z. T. The influence of hormonal conditions on experimental fungus infection in Therapy of Fungus Diseases, T. H. Sternberg and V. D. Newcomer, Eds. New York, Little, Brown, 1955, pp. 90-99.

6. Vogel, R. A., Michael, M., Jr., and Timpe, A. Cortisone in experimental histoplasmosis. Amer. J. Path. 1955, 31, 535.

7. Sylverton, J. T., Werder, A. A., Friedman, J., Roth, F. J., Jr., Graham, A. B., and Mira, O. J. Cortisone and roentgen radiation in combination as synergistic agents for production of lethal infections. Proc. Soc. exp. Biol. (N. Y.) 1952, 80, 123.

8. Seligmann, E. Enhancement of Candida albicans by antibiotics and cortisone. Proc. Soc. exp. Biol. (N. Y.) 1953, 83, 778.

9. Raedaelli, P., Cavallere, C., Borosi, M., Sala, G., and Amira, A. Infezione sperimentele da Coccidiodis immitise steroidi corticosurencli. Mycopathologia (Den Haag) 1951, 6, 7.

10. Baum, G. L., Adriano, S. M., and Schwarz, J. Effect of cortisone on experimental histoplasmosis in mice. Amer. J. clin. Path. 1954, 24, 903.

11. Newcomer, V. D., Wright, E. T., Tarbert, J. E., Winer, L. H., and Sternberg, T. H. The effects of cortisone on experimental coccidiodomycosis. J. invest. Derm. 1953, 20, 315.

12. Truant, J. P., and Tesluk, H. The effect of cortisone upon experimental cryptococcosis. Bact. Proc. 1956, p. 87.

13. Rowley, D. A., and Huber, M. Growth of Histoplasma capsulatum in normal, superinfected, and immunized mice. J. Immunol. 1956, 77, 15.

14. Levy, B. M. Chemotherapy of experimental histoplasmosis in white mice. Amer. J. trop. Med. Hyg. 1945, 25, 241. 
15. Louria, D. B. Specific and non-specific immunity in experimental cryptococcosis in mice. J. exp. Med. 1960, 111, 643.

16. MacKinnon, J. E. Caractares y gradia de la virulencia experimental de las torulospsidaceas de la sub-familia Micotoruleas. An. Fac. Med. Montivideo 1936, 21, 320.

17. Adriano, S. M., and Schwarz, J. Experimental moniliasis in mice. Amer. J. Path. 1955, 31, 859.

18. Pierce, C. H., Dubos, R. J., and Schaefer, W. B. Multiplication and survival of tubercle bacilli in the organs of mice. J. exp. Med. 1953, 97, 189.

19. Smith, J. M. Studies on the fate of virulent and avirulent staphylococci in mice. Ann. N. Y. Acad. Sci. 1956, 65, 67.

20. Wells, A. Q., Agius, E., and Smith, N. Mycobacterium fortuitum. Amer. Rev. Tuberc. 1955, 72, 53.

21. Lovell, R. Studies on Corynebacterium renale. I. A systematic study of a number of strains. J. comp. Path. 1946, 56, 196.

22. Blyth, W. Host-parasite relationships in experimental moniliasis. I. Candida albicans. Mycopathologia (Den Haag) 1958, 10, 269.

23. Evans, W. E. D., and Winner, H. I. The histogenesis of the lesions in experimental moniliasis in rabbits. J. Path. Bact. 1954, 67, 531.
24. Rogers, D. E. Studies on bacteriemia. I. Mechanisms relating to the persistence of bacteriemia in rabbits following the intravenous injection of staphylococci. J. exp. Med. 1956, 103, 713.

25. Freedman, L. R., and Beeson, P. B. Experimental pyelonephritis. IV. Observations on infections resulting from direct inoculation of bacteria in different zones of the kidney. Yale J. Biol. Med. 1958, 30, 406.

26. Beeson, P. B., and Rowley, D. The anticomplementary effect of kidney tissue. Its association with ammonia production. J. exp. Med. 1959, 110, 685.

27. Abernathy, R., and Spink, W. W. The influence of cortisone and adrenocorticotrophic hormone on brucellosis. I. Cortisone in experimentally infected animals. J. clin. Invest. 1952, 31, 947.

28. Bloch, R. G., Vennesland, K., and Gurney, C. The effect of cortisone on tuberculosis in the guinea pig. J. Lab. clin. Med. 1951, 38, 133.

29. LeMaistre, C., Tompsett, R., and McDermott, W. The effects of corticosteroids upon tuberculosis and pseudotuberculosis. Ann. N. Y. Acad. Sci. 1953, 56, 772.

30. Louria, D. B., Browne, H. G., and Stiff, D. The clinical manifestations, pathology and pathogenesis of disseminated moniliasis in man. To be published. 